\title{
Cardiovascular Disease Risk Factors and Mortality in Russia: Challenges and Barriers
}

\author{
Igor S. Petrukhin, $\mathrm{MD}, \mathrm{PhD},{ }^{1}$ \\ Elena Yu Lunina, MD, MPH ${ }^{1}$
}

\begin{abstract}
The article discusses the issue of the high prevalence of cardiovascular risk factors and extremely high mortality rates from cardiovascular disease, especially among people of working ages, in Russia. It justifies the need to reduce excess mortality. Further, it analyzes the trends, structure and the burden of cardiovascular diseases, demonstrates prevalence of major cardiovascular risk factors (psychosocial factors, alcohol abuse, smoking, eating habits, arterial hypertension, low physical activity, obesity, and dyslipidemy) in the Russian population. The measures required to control high mortality from cardiovascular disease and existing barriers in Russia are addressed. A conclusion is made that the lessons learned in western countries over the past 50 years need to be applied in Russia.
\end{abstract}

Key Words: Russia, cardiovascular diseases, mortality, prevention

Recommended Citation: Petrukhin IS, Lunina EY. Cardiovascular disease risk factors and mortality in Russia: challenges and barriers. Public Health Reviews. 2012;33:436-49.

\section{INTRODUCTION}

Cardiovascular diseases (CVD) are a major public health and socioeconomic problem, since they occupy a leading position in the structure of mortality and disability not only in developed but also in developing countries.

At the present time CVD account for 57 percent of all deaths in Russia, while the share of all non-communicable diseases (NCDs) and injuries is about 90 percent. The main diseases that define a high level of mortality from CVD are coronary heart disease and cerebrovascular diseases, which

\footnotetext{
${ }^{1}$ Department of Postgraduate Training in Public Health, and Department of General Practice and Preventive Medicine, Tver State Medical Academy.

Corresponding Author Contact Information: Elena Yu. Lunina at leyu @ mail.ru; Department of General Practice and Preventive Medicine, Tver State Medical Academy, 4, Sovetskaya Str., 170100, Tver, Russia.
} 
are responsible for 49.3 percent and 35.3 percent of deaths, respectively. ${ }^{1} \mathrm{~A}$ distinctive feature of CVD mortality in Russia is that most deaths due to these causes occur in working age groups. It should be noted also that the standardized mortality rate from CVD in Russia is two to three times higher than in developed countries. ${ }^{2}$

\section{CARDIOVASCULAR MORTALITY: TRENDS, STRUCTURE AND BURDEN}

In the 1960s life expectancy in the former Soviet Union for a short period of time approached that of Western countries due to a sharp decline of mortality from infectious diseases. However, between 1965 and 1990, mortality trends in the Soviet Union both in men and women were characterized by a slow growth of CVD and total mortality. This was largely due to the fact that the health care system of the former Soviet Union inadequately responded to the epidemiological transition begun in the 1960s, and the problems of NCD prevention was not given due importance. ${ }^{3}$ While mortality from CVD in Russia continued to grow, in Western Europe and the United States it declined (Figure 1). ${ }^{4}$

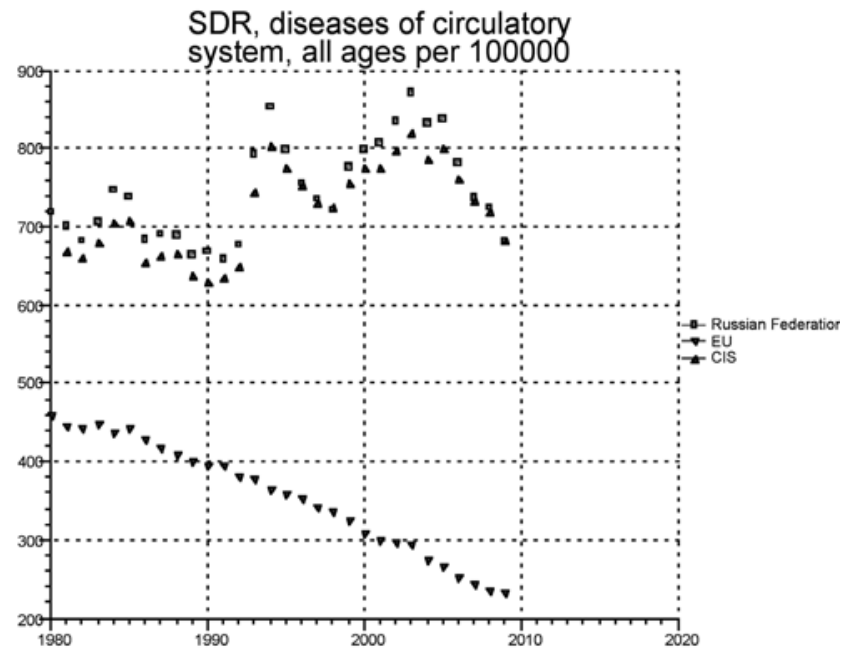

Fig. 1. Standardized death rates (SDR): diseases of the circulatory system, all ages per 100,000, European Region, 1980-2009.

Source: Health for All Data Base, WHO European Region, July 2011. Available from URL: http://www.euro.who.int/HFADB (Accessed 21 September 2011). 
Since the beginning of 1990s CVD mortality rates in Russia, as well as in other Commonwealth of Independent States (CIS) countries, has been substantially higher than that in Western Europe (Figure 1). Large fluctuations in mortality, coinciding with the political and socioeconomic transformations in Russia (e.g., collapse of the USSR in 1992, default of 1998), suggest that the main reason for these fluctuations is a sharp increase in the level of psychosocial stress in various spheres of life of the population. ${ }^{5}$

The deterioration of the health of the Russian population over time coincides with a reduction in public expenditures on health. In the 1990s these expenditures decreased by one third due to a sharp economic recession. Many rural and industrial health care facilities were closed down. Consolidated budget expenditures on health and sports in the years 2000-2005 amounted to only 2.2-2.9 percent of gross domestic product (GDP). It was not until 2006 that they exceeded the pre-Perestroika level (ie., prior to 1991). Total health expenditures in Russia now comprise 5.5 percent of GDP. ${ }^{6}$ For comparison, in the years 1992-2008 health care expenditures in the US accounted for 13-16 percent, in France 9-10.5 percent, and in Germany - 9.9-10.9 percent of GDP. ${ }^{7}$

In recent years a trend to lower CVD mortality has been noted in Russia (Figure 1). Overall, death rates from CVD in the period 2005-2009 decreased from 908.0 to 799.9 per 100,000. ${ }^{8}$ The reduction of CVD death rates in Russia can be mainly explained by the decline of mortality from stroke, while mortality from myocardial infarction has even slightly increased.

Russia is characterized by large regional differences in death rates from CVD. ${ }^{9}$ Thus, the highest number of deaths from these diseases in 2009 was registered in the Northwest region of the country: 1262.8 per 100,000 in the Tver region and 1283.9 per 100,000 in the Pskov region. The lowest mortality from CVD in the same year was registered in the Southern Federal District: 309.3 per 100,000 in Chechnya and 164.7 per 100,000 in Ingushetia. The reasons for such differences require in-depth study.

The total economic cost of CVD in the Russian Federation in 20062009 corresponded to 3 percent of GDP in that period..$^{10}$ Only one fifth of the total economic impact of CVD in 2009 are direct health care costs, while 78.7 percent are indirect social losses associated with premature mortality of men of working age. This indirect damage is very important for Russia's economy, as permanent loss of the labor potential of the country is always a threat to the social and economic welfare of a society ${ }^{10}$ as well as loss of key years of individual and family life. 


\section{CVD RISK FACTORS}

The concept of risk factors (RF) has become the basis for prevention of morbidity and mortality from CVD and other NCDs, and is widely used in clinical and public health practice. ${ }^{5,11-13}$ Smoking, excessive alcohol consumption, unhealthy diet and physical inactivity are the major modifiable RF contributing to mortality. They, in turn, affect such RF as dyslipidemia, obesity, and hypertension, leading to increased morbidity and mortality from CVD.

Russia, unlike the US and other countries, has no established monitoring system for major CVD RF. This makes it impossible to get a complete picture of their prevalence and trends.

\section{Psychosocial factors}

A distinctive feature of Russia is that along with traditional RF, psychosocial factors play an important role in the populations' health. According to Brainerd and Cutler, ${ }^{14}$ stress is a cause of one fourth of the overall mortality increase. A significant stratification of the population into socioeconomic groups with sharp differences in levels of health has begun in Russia. A study carried out in the Vologda region in 1999 demonstrated that in the group of people with the most adverse factors, including the lowest income per household member, the likelihood of poor health was 33 times higher than in the most favorable group. Three fourths of the residents were not adapted to new living conditions in the country, 20 percent of respondents experienced frequent stressful situations, 11.7 percent - severe symptoms of anxiety and 9.6 percent - depression. ${ }^{15}$

Men of lower socioeconomic groups are the highest risk group with excess mortality rates. ${ }^{16}$ The poor are more likely to report regular use of alcohol; they experience more difficulties accessing health care than the rich ${ }^{17}$ However, high mortality rates are not entirely dependent on income level. For example, in 2000 many European countries with lower incomes than Russia had lower mortality rates. ${ }^{8}$

\section{High alcohol intake}

Historically, the inhabitants of Russia have not always been the heaviest drinkers in Europe. However, in the past 20 years, alcohol consumption in Russia remained very high - about ten to 15 liters per person per year, ${ }^{18}$ as compared to 10.3 liters in Sweden and 12.8 liters in Germany. ${ }^{19}$ In 2004 about 70 percent of men, 47 percent of women and 30 percent of teenagers consumed alcohol, 70 percent of the population consumed strong alcoholic 
beverages. ${ }^{20}$ According to the results of a survey held in 2001-2002 alcohol abuse (> $20 \mathrm{~g} /$ day) was found in 30.3-35.3 percent of men and 1.9-3.7 percent of women in the cities of Tver, St. Petersburg and Moscow. ${ }^{21}$ It is possible that these data are underestimated, as a study in the Pitkäranta region using biological markers showed high levels of alcohol consumption in about 37 percent of men and 18 percent of women. In neighboring Finland, these figures were found to be 9.6 percent and 9.4 percent, respectively. ${ }^{22}$

In the years 1980-2001 alcohol consumption was responsible for 25.6 percent of deaths from CVD in men and 15.4 percent in women in Russia (with 194.4 thousand deaths per year). This was the highest contribution to all alcohol deaths (45.6\% of total deaths), and it exceeded the alcoholrelated mortality from external causes. ${ }^{18}$ Affordability of vodka is a key determinant of mortality among working aged men in Russia. ${ }^{23}$ However, Russia has a positive experience with alcohol regulation. From 1985 until 1987 there was an anti-alcoholic campaign, which included higher prices for alcohol products as well as regulation of place and time of sale. As a result, alcohol consumption fell by 20 percent and mortality from CVD and other NCDs declined. The campaign saved one million lives, ${ }^{24}$ but it was quickly stopped for political and economic reasons.

\section{Tobacco smoking}

Russia is a country with one of the world's highest rates of male smokers. According to a survey on a nationally representative sample, 63.2 percent of men and 9.1 percent of women smoked, ${ }^{25}$ as compared to rates of 27 percent and 20 percent in Finland and 29 percent and 25 percent in the United Kingdom, respectively. ${ }^{4}$ The Russian Longitudinal Monitoring Survey (RLMS), ${ }^{20}$ conducted in ten Russian districts, showed that in 1992 the proportions of smokers were 57.4 percent among men and 6.9 percent among women, while in 2002 these rates increased to 62.4 percent and 14.8 percent, and in 2004 - to 61 percent and 15 percent, respectively. Thus, the proportion of female smokers doubled over 12 years and the male smoking rate increased while in parallel rates were declining in most industrialized countries. According to a survey in Moscow, St. Petersburg and Tver in the years 2001-2002 the proportion of female smokers ranged from 19.6 percent to 31.7 percent and male smokers - from 56 percent to 60.3 percent. ${ }^{21}$ The sharp increase in smoking prevalence among women, especially of young ages, is apparently associated with changes in social and economic life in Russia, more liberal public attitudes towards smoking among women, as well as the activity of the tobacco companies and retailers. 
Smoking is the leading cause of most deaths from CVD and other NCDs. About 15 to 20 percent of deaths from CVD in the UK and Central European countries are caused by smoking. In Russia and Kazakhstan, this contribution is the highest at 29 percent. ${ }^{26}$

In 2008, Russia signed the World Health Organization (WHO) Framework Convention on Tobacco Control. However, its implementation is opposed by the tobacco lobby, which has powerful contacts with the political system in the country. Ten years ago already, Cunningham had described the significance of this lobby in Eastern Europe ${ }^{27}$ Vast opportunities taken by the tobacco industry, along with the weakness of non-governmental organizations and health legislation interfere with effective tobacco control measures. ${ }^{28}$

\section{Eating habits}

Dietary intake of Russians is characterized by a high proportion of animal fats and low consumption of fruits, berries and vegetables. Thus, until 1985, the average daily consumption of fat in the Soviet Union was ten to 15 percent higher than the levels recommended by WHO. Since 1992, daily fat consumption has been almost within the normal range, but remained unbalanced due to the high levels of animal fat intake. According to RLMS (2004), ${ }^{20}$ fat consumption in Russia substantially exceeds the WHO recommended levels in all age groups.

From 1990 to 1997 fruits and vegetables intake decreased from 340 grams to 300 grams per person per day, which is far below the amounts recommended by WHO. ${ }^{29}$ More than two thirds of respondents in Moscow, St. Petersburg, and Tver, and respondents in Arkhangelsk and Murmansk in 2001-2002 consumed insufficient amounts of fruits and vegetables. ${ }^{21,30}$

Lower levels of education and income of Russians are associated with higher fat intake and lower consumption of fruits and vegetables, as well as with a lower height; an integral indicator of worse physical development. Male sex, low education and income are significant determinants of unhealthy eating habits. ${ }^{31}$ An approximately 28 percent increase in CVD mortality in Russia can be attributed to insufficient consumption of fruits and vegetables. ${ }^{14}$

Several countries have made significant progress in reducing mortality by developing national food plans and strategies. For example, in Russia's neighbor Finland CVD mortality has declined by more than 50 percent. ${ }^{32}$ And measures to reduce the consumption of fatty dairy and meat products and increased intake of cereals, vegetables, fruits, and berries made a significant contribution to these mortality changes. Russia needs to undertake similar actions in the area of nutrition. 


\section{Hypertension}

Russia is a country with a high prevalence of hypertension. In the 1990s, the prevalence of hypertension (blood pressure (BP) $>140 / 90 \mathrm{~mm} \mathrm{Hg}$.) among men and women over the age of 18 years was 39 percent and 41 percent, respectively, ${ }^{25}$ as compared to the rate of 44 percent in Western European countries and 28 percent in the US and Canada. ${ }^{33}$ According to the results of surveys of the population of Moscow, St. Petersburg and Tver held in 2001-2002, 35.8 to 40.8 percent of men and 33.3 to 35.8 percent of women suffered from hypertension. ${ }^{21}$ It is possible that these data are underestimated because they are based on a self-reported survey, rather than actually measuring BP. According to the results of BP measurements in the Pitkäranta region, 57 percent of men and 55 percent of women were identified to have hypertension. ${ }^{34}$ More than 40 percent of men and 25 percent of women were unaware of their hypertension. ${ }^{34}$

The population attributable fraction of deaths associated with elevated systolic BP, meaning the proportion of deaths that can be attributed to exposure to this factor, is 39 percent and 42 percent for CVD, 41 percent and 34 percent for coronary heart disease and 81 percent and 73 percent for stroke for men (40-50 years) and women (30-69 years), respectively. ${ }^{25}$ The contribution of hypertension to total mortality rates is about 35 percent. Correspondingly, Russian men and women with elevated systolic BP (> $180 \mathrm{~mm} \mathrm{Hg}$ ) live 12.2 years and 6.0 years less than those with normal BP. ${ }^{35}$

The best approach to the existing situation in Russia would be a combination of intensive targeted strategies for primary prevention of hypertension among the population (lowering alcohol consumption, healthy diet, weight control and physical activity) with effective antihypertensive therapy and behavior modification of hypertensive patients.

\section{Physical inactivity and obesity}

Despite the proven benefits of exercise, few people in Russia engage in regular physical activity (PA). In the European Union, only 31 percent of respondents had a sufficient level of PA. ${ }^{36}$

The first standardized study of PA was conducted in the mid-1980s in Moscow in an industrial plant. ${ }^{37}$ Approximately one third of men had low PA both at work and in their leisure time. Half of women were insufficiently physically active in leisure time.$^{37}$ In a survey in Tver in 2001, 56.9 percent of male and 51.4 percent of female workers of an industrial plant reported low PA in their leisure time. ${ }^{38}$ The survey conducted in Russian cities in 2001-2002 found that 73.9-81.7 percent of men and 74.8-86.2 percent of women had low PA uring their free time. ${ }^{21}$ 
In 1992, 47.3 percent of Russian men and 61.8 percent of women were overweight (Body Mass Index (BMI) $>25 \mathrm{~kg} / \mathrm{m}^{2}$ ). ${ }^{25}$ The average value of BMI among male residents of Russia is one of the lowest in Europe, while Russian women are among the most stout. ${ }^{39}$ According to the results of the survey held in 2001-2002 prevalence of overweight among adults 25-64 years of age in Russia cities varied from 48 percent to 54.3 percent in men and from 40.2 percent to 54.0 percent in women. ${ }^{21}$ The average BMI obtained by height and weight measurements in the Pitkäranta region was higher in women $\left(28.0 \mathrm{~kg} / \mathrm{m}^{2}\right)$ and lower in men $\left(25.2 \mathrm{~kg} / \mathrm{m}^{2}\right)$ as compared to Finland. ${ }^{34}$

As the population of Russia is increasingly adopting western lifestyles, including diet and sedentary lifestyles, the prevalence of low PA and obesity will continue to grow and have a serious impact on the health of individuals and the population as a whole, due to elevated BP, high cholesterol levels and type 2 diabetes.

\section{Dyslipidemy}

Average serum cholesterol levels in men and women of Moscow and Novosibirsk in 1989-1997 were among the lowest in Europe. ${ }^{40}$ The levels of high density lipoproteins in adults 20-69 years of age in St. Petersburg were found to be extremely low. ${ }^{41}$ The average levels of cholesterol in the blood serum in the Pitkäranta region were $5.2 \mathrm{mmol} / \mathrm{L}$ in men and 5.3 $\mathrm{mmol} / \mathrm{L}$ in women, and they were below the levels of cholesterol in Finns. ${ }^{34}$

Despite the fact that cholesterol levels in the Russians are somewhat lower than in the population of Western countries, there is a need for constant monitoring of blood lipids for the adequate prevention of CVD.

\section{MEASURES TO CONTROL HIGH CARDIOVASCULAR MORTALITY}

The first research on the prevalence of behavioral RF of CVD and other NCDs in Russia using standard protocols began in the 1980s, with the development of Countrywide Integrated Noncommunicable Diseases Intervention Programme (CINDI), a WHO sponsored international comparative effort to document cardiovascular RF and effective interventions. ${ }^{42,43}$ The experience of behavior change towards more healthy habits has accumulated in the 20 Russian CINDI regions. ${ }^{42,44}$ The first papers on CVD and other NCD prevention policies were developed as a part of CINDI. ${ }^{42}$ 
Russian research projects of the hypertension control ${ }^{45}$ and coronary heart disease prevention in $\operatorname{men}^{46}$ have demonstrated the possibility of reducing mortality from stroke and coronary heart disease. An educational program for RF prevention in children was successfully implemented. ${ }^{47}$ However, these programs had no further development on a national scale.

An important step in the development of prevention of CVD and other NCDs was the creation of a multidisciplinary inter-sectoral document "Strategy for Prevention and Control of Noncommunicable Diseases and Injuries in the Russian Federation" developed in 2008 by Russian and international experts. ${ }^{48}$ It clearly defined the basic steps for prevention:

1. the formation of federal and regional policy, the definition of funding sources and mechanisms;

2. the development and improvement of legal and regulatory frameworks;

3. health care system measures;

4. training of personnel;

5. public education;

6. establishment of a RF monitoring system; and

7. international cooperation. We can only expect the implementation of the document into practice.

\section{Existing barriers}

The need for prevention is mentioned in many Russian documents and regulations. However, the proclamation of the prevention of CVD and other NCDs as a strategic direction for health care development has been primarily declarative in nature ${ }^{49}$ Existing barriers include: contradicting interests of partners; existence of monopolies (in the trade, media, advertising, etc.); lack of adequate legislation; lack of a critical mass of professionals and expertise in the field of NCD prevention and control; lack of resources and materials; lack of consistency in the development of health systems and policy-making; lack of leadership and coordination in the Ministry of Health; vague financial responsibility; competing priorities (e.g., treatment vs. prevention) or a lack of interest and political commitment among key stakeholders and policy makers; and lack of comprehensive guidelines for planning, implementation and evaluation of prevention and control.

Implementation of the New Public Health approaches seems particularly relevant to overcome the current situation in Russia. ${ }^{3}$ 


\section{CONCLUSIONS}

Russia needs to increase investment in health to reduce poverty and disparities in health. Determining the strategy and development of programs for CVD and other NCD prevention requires taking into account regional specificities, identification of risk groups and specific areas of activity. State policy (support), inter-sectoral collaboration as well as sufficient human (professional) and material resources are needed to guarantee the effectiveness of these programs. Large-scale inter-sectoral actions aimed at the prevention and correction of the main RF can lead to a significant reduction in mortality from CVD and other NCDs in Russia.

The lessons learned in western countries over the past 50 years need to be applied in Russia to address this terrible burden on Russian society. The health system, previously a pride of the Soviet Union, has failed to address the most important NCDs. The management of hypertension and development of health promotion measures to address dietary habits, smoking and lack of physical activity are critical to the further reduction of the mass premature deaths due to CVD of Russian men and to a lesser extent women. The well being of the Russian people depends on this as much as it does on economic prosperity.

\section{Acronyms List:}

BMI=Body Mass Index

$\mathrm{BP}=\mathrm{Blood}$ Pressure

CINDI=Countrywide Integrated Noncommunicable Diseases Intervention Programme CIS = Commonwealth of Independent States

$\mathrm{CVD}=$ Cardiovascular Diseases

GDP $=$ Gross Domestic Product

NCDs=Non-Communicable Diseases

$\mathrm{PA}=$ Physical Activity

RF=Risk Factors

RLMS=Russian Longitudinal Monitoring Survey

WHO=World Health Organization

Acknowledgements: The authors would like to thank Professor Theodore H. Tulchinsky for his valuable comments on a draft of the manuscript.

Conflicts of Interest: None declared 


\section{REFERENCES}

1. Demoscope Weekly. 6-19 June, 2011:469-70. Available from URL: http:// demoscope.ru/weekly/2011/0469/barom04.php (Accessed 23 September, 2011).

2. Kharchenko VI, Kakorina YeP, Koryakin MV, Virin MM, Udrintsov VM, Smirnova NL, et al. Mortality from circulatory diseases in Russia and in developed countries. The need to strengthen the cardiological service and modernize of medical statistics in the Russian Federation (Analytical review of official data of Goskomstat, Ministry of Health and Social Development of Russia, WHO and expert analysis on the issue). Rossiyskiy Kardiologicheskiy Zhurnal. 2005;2:2-10.

3. Tulchinsky TH, Varavikova EA. The New Public Health: an introduction for the 21st century. 2nd ed. San Diego, CA: Academic Press; 2008.

4. World Health Organization. Health for All Data Base. WHO European Region. July 2011. Available from URL: http://www.euro.who.int/HFADB (Updated July, 2011 and accessed 21 September, 2011).

5. Oganov RG, Maslennikova GYa. Noncommunicable diseases in Russia, the role of risk factors. In: Glazunov IS, Stachenko S, editors. Health promotion and prevention of noncommunicable disease in Russia and Canada. Experience and recommendations. Public Health Agency of Canada; 2006. p.3-18.

6. World Bank. Reforming the health care system of the Russian Federation with a view to improving the health of the population: The main objectives for 2008 and beyond. World Bank. Region: Europe and Central Asia. Department of Social Programs. Country: Russian Federation.

7. Kalabekov IG. Russian reforms in figures and facts. 2010. Available from URL: http://kaivg.narod.ru (Updated November, 2010 and accessed 21 September, 2011).

8. Marquez PV. Dying too young. Addressing premature mortality and ill health due to non-communicable diseases and injuries in the Russian Federation (Summary). Washington, DC: World Bank; 2005.

9. Federal State Statistic Service. The Demographic Yearbook of Russia. Statistical Handbook. Moscow: Federal State Statistic Service (Rosstat); 2010.

10. Oganov RG, Kontsevaya AV, Kalinina AM. Economic burden of cardiovascular disease in the Russian Federation. Kardiovasculyarnaya Terapiya I Profilaktika. 2011;10:4-19.

11. Oganov RG, Maslennikova GYa, Shalnova SA, Deev AD. The value of risk factors management for the prevention of chronic noncommunicable diseases. Profilac Zabol Ukrep Zdor. 2005;5:22-5.

12. Shalnova SA, Deev AD, Oganov RG. Factors influencing the mortality from cardiovascular disease in Russian population. Kardiovasculyarnaya Terapiya I Profilaktika. 2005;4:4-9. 
13. Rodionov AA, Petrukhin IS. Physical activity of workers of a large industrial enterprise and its correction. Profilac Zabol Ukrep Zdor 2008;4:42-6.

14. Brainerd E, Cutler DM. Autopsy on an Empire: Understanding Mortality in Russia and the Former Soviet Union. NBER Working paper 10868, National Bureau of Economic Research, Cambridge, MA; 2004. Available from URL: http://www.nber.org/papers/w10868 (Accessed 10 September, 2011).

15. Aarva P, Zhukovsky GS, Marsimova TM, Martynchik EA, Oganov RG. Social inequality in the health level of the population: self-appraisal in one-stage study in the Vologda region. Profilac Zabol Ukrep Zdor. 2000;3:3-9.

16. Plavinsky SL, Plavinskaya SI, Klimov AN. Social factors and increases in mortality in Russia in the 1990s: prospective cohort study. BMJ. 2003;326:1240-2.

17. Federal State Statistics Service. NOBUS (National Survey of Household Welfare and Program Participation). Moscow: Federal State Statistics Service; 2003.

18. Nemtsov AV, Terekin AT. Alcohol-associated cardiovascular mortality in Russia. Profilac Zabol Ukrep Zdor. 2008;2:23-30.

19. World Health Organization. WHO Global Status Report on Alcohol and Health 2011. Geneva: WHO; 2011. Available from URL: http://www.who.int/ substance_abuse/publications/global_alcohol_report/msbgsreur.pdf (Accessed 21 September, 2011).

20. Carolina Population Center. The Russia Longitudinal Monitoring Survey Higher School of Economics. University of North Carolina. Available from URL: http://www.cpc.unc.edu/projects/rlms-hse (Accessed 10 September, 2011).

21. Potemkina RA, Glazunov IS, Kuznetsova OYu, Petrukhin IS, Frolova YeV, Kudina YeA, et al. Examination of the spread of behavioral risk factors among the population of Moscow, Saint Petersburg, and Tver by telephone questioning. Profilac Zabol Ukrep Zdor 2005;3:3-15.

22. Laatikainen T, Alho H, Vartianinen E, Jousilahti P, Sillanaukee P, Puska P. Selfreported alcohol consumption and association to carbohydrate-deficient transferring and gamma-glutamyltransferase in a random sample of the general population in the Republic of Karelia, Russia and in North Karelia, Finland. Alcohol and Alcoholism. 2002;37:382-8.

23. Treisman D. Alcohol and Early Death in Russia: The political economy of selfdestructive drinking. Moscow: Moscow State University - Higher School of Economics; 2008.

24. Nemtsov AV. Alcohol-attributed mortality in Russia, 1980-1990s. Moscow; 2001.

25. Shalnova SA. Cardiovascular risk factors and life expectancy of the population of Russia (the results of the research on a national representative sample): Thesis. Moscow; 1999.

26. Maslennikova GYa, Oganov RG. Impact of smoking on health of population in Russia and Europe. Profilac Zabol Ukrep Zdor 2002;6:17-20,29. 
27. Cunningham R. Smoke and Mirrors. The Canadian Tobacco War. Ottawa: IDRC Books; 1996.

28. Gilmore AB, McKee M. Tobacco and transition: an overview of industry investments, impact and influence in the former Soviet Union. Tob Control. 2004; 13:136-42.

29. Baturin AK. Development of an evaluation system and characteristics of food intake and nutrition status in Russia: Thesis. Moscow; 1998.

30. Popovich MV, Glazunov IS, Potemkina RA, Kamardina TV, Deev AD, Starovoitov ML, et al. Consumption of fruit and vegetables in Moscow, Murmansk and Arkhangelsk. Profilac Zabol Ukrep Zdor. 2002;6:30-3.

31. Platonov DYu, Petrukhin IS, Volkov VS. Some dietary habits in the adult population of the tver Region and their association with demographic and socioeconomic factors. Profilac Zabol Ukrep Zdor 2007;1:28-36.

32. Puska P, Tuomilehto J, Nissenen A, Vartiainen E. The North Karelia Project. 20 years results and experiences. Helsinki: Helsinki University Press; 1995.

33. Wolf-Maier K, Cooper RS, Banegas JR, Giampaoli S, Hense HW, Joffres M, et al. Hypertension prevalence and blood pressure levels in 6 European countries, Canada, and the United States. JAMA. 2003;289:2363-9.

34. Laatikainen T. Cardiovascular Risk in the Republic of Karelia, Russia: Comparison of Major Risk Factors with North Karelia, Finland. Thesis. Helsinki: National Public Health Institute; 2000.

35. Oganov RG, Shalnova SA, Maslennikova GYa, Deev AD. The role of healthy lifestyle strategies for public health protection. Ross Med Vesti. 2001;3:34-7.

36. Sjostrom M. Health-enhancing physical activity across European Union countries: the Eurobarometer study. J Public Health. 2006;14:1-10.

37. Zabina E, Muravov O. Experience in validation and use of CINDI physical activity questionnaire. - Copenhagen: World Health Organization, Regional Office for Europe; 1995.

38. Rodionov AA. Prevention of low physical activity and psychological dysadaptation as risk factors of cardiovascular diseases among workers of an industrial plant. Thesis. Tver; 2009.

39. World Health Organization. The world health report. Life in the 21st century: A vision for all. Geneva: WHO; 1998.

40. WHO MONICA Project. Geographical variation in the major risk factors of coronary heart disease in men and in women aged 35-64 years. World Health Stat Q. 41:115-40.

41. Plavinsky SL, Plavinskaya SI, Klimov AN. Social factors and mortality increase in Russia in 1990s. The role of education and alcohol. In: Population's health. Collection of scientific and practical articles. Moscow: Open Health Institute; 2005. p.98-110.

42. Glasunov IS. CINDI - Countrywide Integrated Noncommunicable Diseases Intervention Programme. In: Glazunov IS, Stachenko S, editors. Health promotion and prevention of noncommunicable disease in Russia and Canada. Experience and recommendations. Public Health Agency of Canada; 2006. p.30-4. 
43. Morgenstern W, Tsechkovski MS, Nussel E, Schettler G. Baseline Evaluation. CINDI. WHO/EURO and Springer-Verlag; 1991.

44. Popugaev AI, Kalinina AM, Shalnova SA, Deev AD, Kontsevaya AV, Nechaev VS, et al. The epidemiological situation with regard to major risk factors and total cardiovascular risk in the population of Vologda 35-64 years of age. Kardiovasculyarnaya Terapiya I Profilaktika. 2008;7:13-9.

45. Britov AN, Sapozhnikov II, Konstantinov EN. The control of arterial hypertension in the population. In: Preventive Cardiology. Chazov EI, Oganov RG, editors. Moscow: International Universities Press, Inc; 1989. p.149-86.

46. Kalinina AM. Influence of multifactorial prevention of coronary hearth disease on some indicators of health and life prognosis (10-years follow-up). Thesis. Moscow; 1993.

47. Alexandrov AA, Maslennikova GYa, Kulikov SM, Propirnij GA, Perova NV. Primary prevention of cardiovascular disease: 3-year intervention results in boys of 12 years of age. Prev Med 1992;21:53-62.

48. Ministry of Health and Social Development of the Russian Federation. Strategy for prevention and control of noncommunicable diseases and injuries in the Russian Federation. Moscow: Ministry of Health and Social Development of the Russian Federation. State Research Center for Preventive Medicine; 2008.

49. Vyalkov AI. Policy and strategy of diseases prevention and health promotion in contemporary society. Obsch Zdor Prof Zab. 2003;1:3-7. 